\title{
Arbuscular mycorrhizal fungal activity responses to winter cover crops in a sunflower and maize cropping system
}

\author{
Irene García-González, Miguel Quemada, José Luis Gabriel, Chiquinquirá Hontoria* \\ Department of Agrarian Production, School of Agriaultural Engineering Technical University of Madrid (UPM), Spain
}

\section{ARTICLE INFO}

\section{Article history:}

Received 24 July 2015

Received in revised form 3 February 2016

Accepted 12 February 2016

Available online $x x x$

\section{Keywords:}

Barley

Vetch

Arbuscular mycorrhizal fungi

Glomalin

$\beta$-glucosaminidase activity

Water-stable aggregates

\begin{abstract}
A B S T R ACT
The symbiosis between plants and arbuscular mycorrhizal fungi (AMF) benefits the health, nutrition and abiotic stress tolerance of the host plant. The maintenance of potential AMF inoculum in the winter is important because it will affect the colonization process in the subsequent crop. The objective of this study was to evaluate the effect of winter cover crops (CC) on AMF parameters (root colonization, length of hyphae and number of AMF spores), other variables indirectly related to AMF (the easily extractable glomalin-related soil protein (EE-GRSP) and the enzymatic activity of $\beta$-glucosaminidase), along with water-stable aggregates (WSA) as a soil quality indicator. In addition, the effect of two sampling dates on the variables in maize and the relationships among all of the variables were studied. The samples were obtained from a field experiment established in 2006 located in Aranjuez (Central Spain) under a Mediterranean semiarid climate. The treatments were winter cover crops of barley (Hordeum vulgare L.) or vetch (Vicia villosa L) and fallow as a control. The study covered two seasons in 2011-12 and 2012-13 with sunflower (Helianthus annuus L) and maize (Zea mays L) as the main crop, respectively, with both sown in the spring. The main crops were irrigated according to the crop demand. Compared with the bare fallow conditions, cover crops improved most of the variables, maintaining the benefits of $\mathrm{CC}$ on AMF under the semiarid conditions of the Mediterranean climate. Barley as a cover crop gave the best results, whereas the performance of vetch was poorer. In sunflower, barley increased by $80 \%$ the hyphae length and $\beta$-glucosaminidase activity and by $30 \%$ other variables compared with the fallow; whereas in maize, 60-70\% increments were found in AMF spores and the hyphae length and 2-fold in the enzyme activity. The sampling date affected all of the variables analyzed in the maize crop, except for the EE-GRSP and the WSA. Positive relationships were found between the variables directly related to AMF, EE-GRSP content and $\beta$-glucosaminidase activity. This suggests that the variables indirectly related to AMF, mainly the EE-GRSP, could be used as indicators of AMF. Finally, the enhancement of soil aggregate stability by the CC via AMF promotion was corroborated.
\end{abstract}

단 2016 Elsevier B.V. All rights reserved.

\section{Introduction}

Wenter over ctowa ift) mavent soil erocion (bowran and

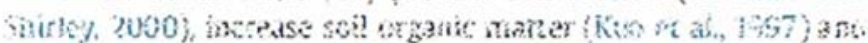

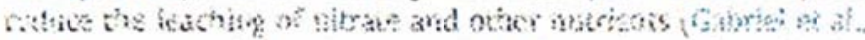

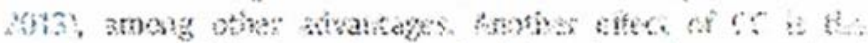

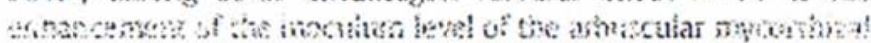

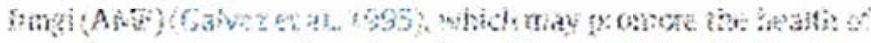

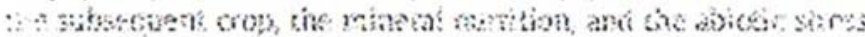

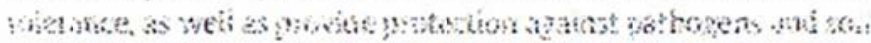

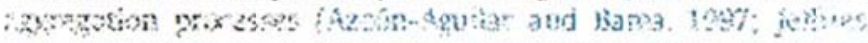

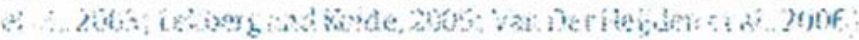

\footnotetext{
- Corresponding author.

E-mail address: c.hontoria@upm.es (C. Hontoria).
}

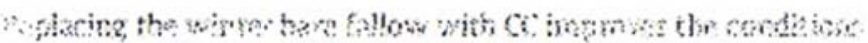

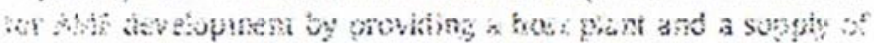

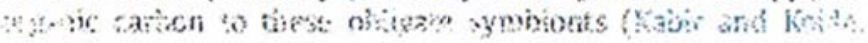

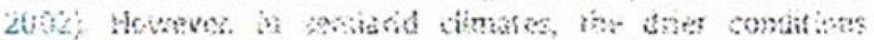

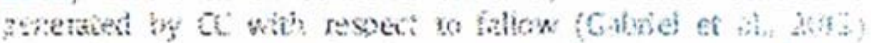

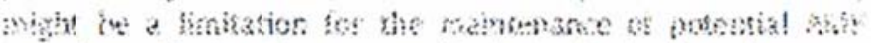

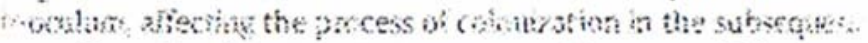

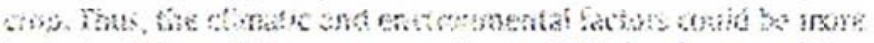

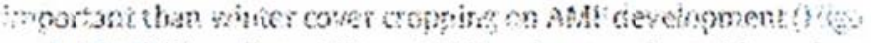

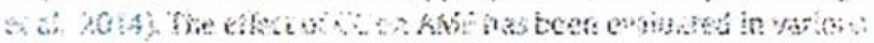

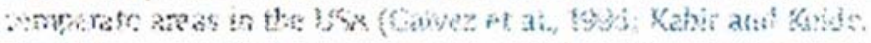

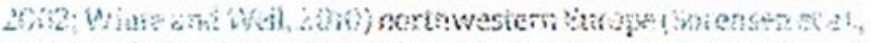

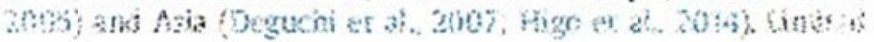

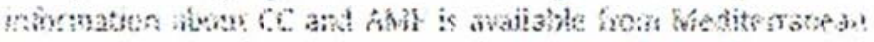

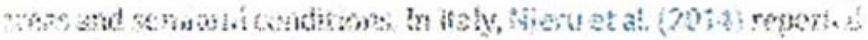

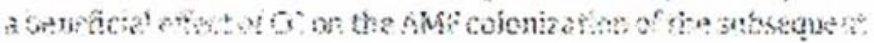




\section{Introduction}

Winter cover crops (CC) prevent soil erosion (Bowman and Shirley, 2000), increase soil organic matter (Kuo et al., 1997) and reduce the leaching of nitrate and other nutrients (Gabriel et al., 2013), among other advantages. Another effect of CC is the enhancement of the inoculum level of the arbuscular mycorrhizal fungi (AMF) (Galvez et al., 1995), which may promote the health of the subsequent crop, the mineral nutrition, and the abiotic stress tolerance, as well as provide protection against pathogens and soil aggregation processes (Azcón-Aguilar and Barea, 1997; Jeffries et al., 2003; Lekberg and Koide, 2005; Van Der Heijden et al., 2006).

Replacing the winter bare fallow with $\mathrm{CC}$ improves the conditions for AMF development by providing a host plant and a supply of organic carbon to these obligate symbionts (Kabir and Koide, 2002). However, in semiarid climates, the drier conditions generated by CC with respect to fallow (Gabriel et al., 2012) might be a limitation for the maintenance of potential AMF inoculum, affecting the process of colonization in the subsequent crop. Thus, the climatic and environmental factors could be more important than winter cover cropping on AMF development (Higo et al., 2014). The effect of CC on AMF has been evaluated in various temperate areas in the USA (Galvez et al., 1995; Kabir and Koide, 2002; White and Weil, 2010) northwestern Europe (Sorensen et al., 2005) and Asia (Deguchi et al., 2007; Higo et al., 2014). Limited information about CC and AMF is available from Mediterranean areas and semiarid conditions. In Italy, Njeru et al. (2014) reported a beneficial effect of CC on the AMF colonization of the subsequent organic maize crop. Other studies in the Mediterranean areas of SE Spain reported the effects of management practices on AMF (Alguacil et al., 2014), but most of the research is focused on natural ecosystems (Barea et al., 2011; Ortiz et al., 2015). Additional investigations in cropping systems under Mediterranean conditions are required to clarify whether the positive effect of CC on AMF is maintained through their mild and relatively dry winter conditions.

Most studies of the influence of management practices on AMF have focused on root colonization as a measurement of fungal abundance. In addition, some propagules as number of spores or extra-radical hyphal measurements are often determined to quantify the inoculum potential for infection. Especially the extra-radical hyphal length determination would be a good option to measure the AMF abundance in the soil, due to the fact that not all AMF produce spores (Morton and Redecker, 2001) and that would result in a limitation to the methods of spore count. Compared with fallow conditions, CC increased the root colonization of the subsequent crop in a temperate climate, for example, in maize (Kabir and Koide, 2000, 2002; Lehman et al., 2012; White and Weil, 2010), leeks (Sorensen et al., 2005) and soybean (Higo et al., 2014). However, other crops, such as sunflower, that are typical in rotations in Mediterranean 
areas have received no attention. Differences in colonized root length are likely to be observed after main crop planting, and they may disappear over time (Gavito and Miller, 1998; Sorensen et al., 2005); for this reason, sampling should be conducted in the early crop stages. At that time, AMF infection may be more important because it can be decisive in the success of the seedling establishment phase (Boswell et al., 1998). Therefore, the influence of the sampling date should be considered along with the effect of the CC on AMF.

Cover crops can affect other soil variables, such as glomalin, an insoluble and hydrophobic proteinaceous substance, which is a component of the hyphae and spore walls of AMF (Driveretal.,2005). Glomalin has a slow turnover rate (Steinberg and Rillig, 2003) and can accumulate in soils (Rillig et al., 2001b) where it enhances the stabilization of soil aggregates (Rillig and Mummey, 2006). While parameters traditionally used to measure AMF (root colonization or length of hyphae) are complex and time-consuming, some of the glomalin fractions, such as the glomalin-related soil proteins (GRSPs), are easily measured. Because studies found a positive correlation between GRSPs and parameters directly related to AMF (Bedini et al., 2007; Peng et al., 2013), GRSP might be used as a simple indicator of AMF. However, many studies found no relationship between the content of this protein and the AM fungal parameters (Lovelock et al., 2004; Lutgen et al., 2003; Rillig et al., 2001a; Wright et al., 1999; Wright and Upadhyaya, 1999), which may call into question its ability to indicate AMF abundance. Glomalin is also of interest due to its role in microaggregate and macroaggregate formation and stabilization (Rillig and Mummey, 2006), contributing to the explanation of the positive effect of AMF on soil structure (Bronick and Lal, 2005). Because the percentage of water-stable aggregates (WSA) is an important physical indicator used to evaluate soil structure, it was included in this study to test the positive effects of CC on aggregation through AMF enhancement, as well as to examine its relationship with glomalin. Among all of the biological soil properties, enzyme activities are the most sensitive indicator of soil quality changes related to land use, soil management and environmental stress (Ekenler and Tabatabai, 2003). The enzymatic activity of $\beta$-glucosaminidase is responsible for degrading chitin, a major structural compound in insects and fungal cell walls that is abundant in the soil and plays a key role in C and N cycling (Geisseler and Horwath, 2009). Some studies (Andersson et al., 2004; Miller et al.,1998; Reeslev et al., 2003) showed how the $\beta$-glucosaminidase activity was related to fungal biomass so that it could be used as a simple and sensitive indicator of soil fungal biomass.

The general objective of this study was to determine whether replacing the traditional winter fallow in Mediterranean areas with CC would enhance AMF activity. The specific objectives were as follows: (i) to evaluate the CC effect on several variables related to AMF under two different main crops, sunflower and maize, and (ii) to study the relationships among the variables directly and 
indirectly related to AMF. The directly related variables were the percentage of mycorrhizal colonization, the length of extra-radical mycelium and the number of AM fungal spores. The indirect variables were the soil content of the easily extractable fraction of the GRSP and $\beta$-glucosaminidase activity. Finally, the percentage of soil water-stable aggregates was selected as an indicator of the benefits of AMF to soil quality.

\section{Materials and methods}

\subsection{Study site and experimental design}

The study was conducted during two seasons (2011-12 and 2012-13) at La Chimenea Field Station ( $40^{\circ} 03^{\prime} \mathrm{N}, 03^{\circ} 31^{\prime} \mathrm{W}, 550 \mathrm{~m}$ a.s.l.) in the central Tajo River basin near Aranjuez (Madrid, Spain) in a trial established in 2006. The soil was classified as Typic Calcixerept (Staff, 2003) with the following top soil (0-20 $\mathrm{cm})$ properties in 2012: $\mathrm{pH}_{\text {water }}(1: 2.5), 8.4$; organic matter, $1.8 \%$; calcium carbonate, $15.7 \%$; sand $(2000-50 \mathrm{~mm})$, silt $(50-2 \mathrm{~mm})$ and clay $(<2 \mathrm{~mm})$ content, 290, 420 and $290 \mathrm{~g} \mathrm{~kg}^{-1}$, respectively, and loam textural class. The climate of this area is Mediterranean semiarid (Papadakis, 1966). The mean annual temperature is $14.2^{\circ} \mathrm{C}$, and the mean annual precipitation is $350 \mathrm{~mm}$. Measurements of temperature, humidity, radiation, and wind were recorded throughout the experimental period in a CR23X micro-logger from Campbell Scientific (Logan, Utah, USA).

Twelve plots $\left(12 \times 12 \mathrm{~m}^{2}\right)$ were randomly distributed in four replications of three treatments: barley (Hordeum vulgare L., cv. Vanesa) and vetch (Vicia villosa L., $\mathrm{cv}$. Vereda) as CC during the fall-winter period, with fallow as the control. The cover crops were disseminated by hand over the stubble of the previous crop and covered with a shallow cultivator $(\sim 5 \mathrm{~cm}$ depth) that passed over all of the plots in October (18/10/2011 and 05/10/2012). All of the plots were treated with one application of glyphosate $2 \%$ (N-phosphonomethyl glycine) in March to terminate the CC. The main crop was sown in early spring over the chopped CC residue by direct sowing. The first year, sunflower (Helianthus annuus L., var. Sanbro) was sown (20/04/2012), and the second year, maize (Zea mays L., G98 Pioneer) was sown (18/04/2013). The main crop was harvested in early autumn (sunflower on 12/09/2012 and maize on 07/10/2013). Water was uniformly applied using a sprinkler irrigation system (12x12 m, $\left.9.5 \mathrm{~mm} \mathrm{~h}^{-1}\right)$ according to crop evapotranspiration (ETc) requirements calculated by the FAO method (Allen et al., 1998). Additional details about the soil and the experimental site can be found in the literature (Gabriel and Quemada, 2011). Throughout the experiment, all plots received the same amount of synthetic fertilizer. From 2006 to 2011, ammonium nitrate $\left(210 \mathrm{~kg} \mathrm{~N} \mathrm{ha}^{-1}\right)$ split into two applications when maize had 4 and 8 leaves, and before sowing the main crop $120 \mathrm{~kg} \mathrm{P} \mathrm{ha}^{-1}$ as triple superphosphate and $120 \mathrm{~kg} \mathrm{~K} \mathrm{ha}^{-1}$ as potassium sulfate. 
Fertilization was suspended in 2012 and 2013. Cover crop residues remained in the field, whereas the maize and sunflower residues were removed from the experiment, leaving the same amount $\left(\sim 1000 \mathrm{~kg} \mathrm{ha}^{-1}\right)$ in all of the plots. A summary of the experimental history is shown in Table 1.

Table 1.Summary of the experiment history at La Chimenea field in Aranjuez (Madrid, Spain).

\begin{tabular}{lllll}
\hline Campaign & Crop & Sowing & $\begin{array}{l}\text { Harvest or } \\
\text { CC killing }\end{array}$ & $\begin{array}{l}\text { Fertilization } \\
\left(\mathrm{kg} \mathrm{N}^{\mathrm{P}} \mathrm{O}_{5}-\mathrm{K}_{2} \mathrm{Oha}^{-1}\right)\end{array}$ \\
\hline \multirow{2}{*}{$2006-07$} & Maize & $05 / 04 / 2006$ & $25 / 09 / 2006$ & $210-120-120$ \\
& CC/Fallow & $05 / 10 / 2006$ & $22 / 03 / 2007$ & - \\
& Maize & $17 / 04 / 2007$ & $08 / 10 / 2007$ & $210-120-120$ \\
$2007-08$ & CC/Fallow & $11 / 10 / 2007$ & $24 / 03 / 2008$ & - \\
& Maize & $16 / 04 / 2008$ & $02 / 10 / 2008$ & $210-120-120$ \\
$2008-09$ & CC/Fallow & $09 / 10 / 2008$ & $11 / 03 / 2009$ & - \\
& Maize & $03 / 04 / 2009$ & $29 / 09 / 2009$ & $210-120-120$ \\
$2009-10$ & CC/Fallow & $05 / 10 / 2009$ & $15 / 03 / 2010$ & - \\
& Maize & $13 / 04 / 2010$ & $07 / 10 / 2010$ & $210-120-120$ \\
$2010-011$ & CC/Fallow & $15 / 10 / 2010$ & $14 / 04 / 2011$ & - \\
& None & - & - & - \\
$2011-12$ & CC/Fallow & $06 / 10 / 2011$ & $30 / 03 / 2012$ & - \\
& Sunflower & $20 / 04 / 2012$ & $12 / 09 / 2012$ & - \\
$2012-13$ & CC/Fallow & $05 / 10 / 2012$ & $13 / 03 / 2013$ & - \\
& Maize & $18 / 04 / 2013$ & $07 / 10 / 2013$ & - \\
\hline
\end{tabular}

\subsection{Field measurements, sampling and laboratory analysis}

The soil water content was monitored periodically in this study using the Diviner1 capacitance probe (Sentek Pty Ltd., Stepney, Australia) that was described in detail by Paltineanu and Starr (1997). Nine access pipes (three repetitions per treatment) were installed in the plots. The probe was introduced once a week to measure the soil water content by centering the sensor at a 10 $\mathrm{cm}$ depth. The average readings were transformed into soil volumetric water content using a calibration equation that was obtained at the experimental site (Gabriel et al., 2010).

Five plants were randomly selected from each plot. The plants were dug carefully ( $\sim 10 \mathrm{~cm}$ each side) and the root system together with the soil were extracted. The first year, samples were taken 95 days after sowing (DAS) sunflower (24/07/2012), with 1267 accumulated degree-days (DD). The accumulated DD was calculated with a base temperature of $8^{\circ} \mathrm{C}$. The second year, samples were taken on two dates, at 54 DAS (11/06/2013; 420 DD accumulated) and at 69 DAS (26/06/2013; 650 DD accumulated) after maize planting. The maize growth stages of the first and second sampling were V5 (5 leaves fully extended) and V7 (7 leaves fully extended), respectively (Ritchie et al., 1992).

In the laboratory, the roots and the soil from each sample were carefully separated and a composed sample of each part was obtained per plot. The 
roots were washed with water, cut into $1-2 \mathrm{~cm}$ pieces, cleared with $10 \% \mathrm{KOH}$, acidified with diluted $\mathrm{HCl}$, and stained with a $0.05 \%$ solution of trypan blue in lactoglycerol (Phillips and Hayman, 1970) to estimate root mycorrhizal colonization by the grid-line intersect method (Giovannetti and Mosse, 1980). The length of the extra-radical mycelium was measured in the soil samples by a combination of methods described by Kabir et al. (1997) and Jakobsen et al. (1992). A soil subsample $(2 \mathrm{~g})$ was blended for $30 \mathrm{~s}$ with distilled water. This suspension was then poured through a $250-\mathrm{mm}$ sieve and then a $50-\mathrm{mm}$ sieve to separate the hyphae. The recovered material was suspended again in water, transferred to a beaker, shaken for $60 \mathrm{~s}$, and left to settle for $10 \mathrm{~min}$. A $20 \mathrm{ml}$ aliquot was stained with trypan blue $(12 \mathrm{~h})$ and filtered through a Whatman membrane filter $(0.45 \mathrm{~mm}$ diameter pores) under vacuum. The hyphae were counted under a microscope, and the hyphae length was calculated according to Tennant (1975). The AM fungal spores were isolated from the soil samples by wet sieving and decanting, followed by sucrose centrifugation (Sieverding, 1991). The number of AMF spores per gram of soil was counted using a microscope.

The glomalin content was estimated by the measurement of the easily extractable glomalin-related soil protein (EE-GRSP), which is considered the most recent deposition fraction (Wright and Upadhyaya, 1998). EE-GRSP was extracted from soil samples with $20 \mathrm{mM}$ sodium citrate at $\mathrm{pH} 7.0$ and $121^{\circ} \mathrm{C}$ for 30 min (Wright and Upadhyaya, 1998). The protein content of the extracts was quantified using the Bradford protein assay with bovine serum albumin as the standard. The $\beta$-glucosaminidase activity was determined using the method of Parham and Deng (2000) in which subsamples are assayed with r-nitrophenyl$\mathrm{N}$-acetyl- $\beta$-D-glucosaminide as substrate and incubated for $1 \mathrm{~h}\left(37^{\circ} \mathrm{C}\right)$. The WSA were determined by wet-sieving of air-dried 1-2 $\mathrm{mm}$ aggregates through a $250 \mathrm{~mm}$ sieve (Kemper and Rosenau, 1986). All of the laboratory analyses were performed in duplicate, and an average was calculated.

\subsection{Statistical analysis}

Statistical analysis was performed using the program Stat- graphics Centurion $\mathrm{XVI}$. Each variable was examined using analysis of variance (ANOVA), and the mean comparisons were made using Fisher's Least Significant Difference test at the 0.05 probability level $(P \leq 0.05)$. ANOVA assumptions of normality and homoscedasticity were checked. Pearson's product-moment between variables and their significance levels were also calculated.

\section{Results}

\subsection{Soil water content evolution}

In the 2011-12 campaign, the precipitation during the CC/fallow period was 174 $\mathrm{mm}$, whereas in 2012-13, the precipitation was $288 \mathrm{~mm}$. In both periods, the 
lowest soil water content was found in the barley, and the highest in the fallow treatment, with vetch in between these values (Fig. 1). As the CC grew and took up water, the soil water content values diverged. During the periods of the productive crop, soil moisture followed the irrigation cycles and tended to equalize in all of the plots; only occasional differences appeared between treatments. At the time when soil samples were taken for this study, no differences in soil water content between treatments were observed.

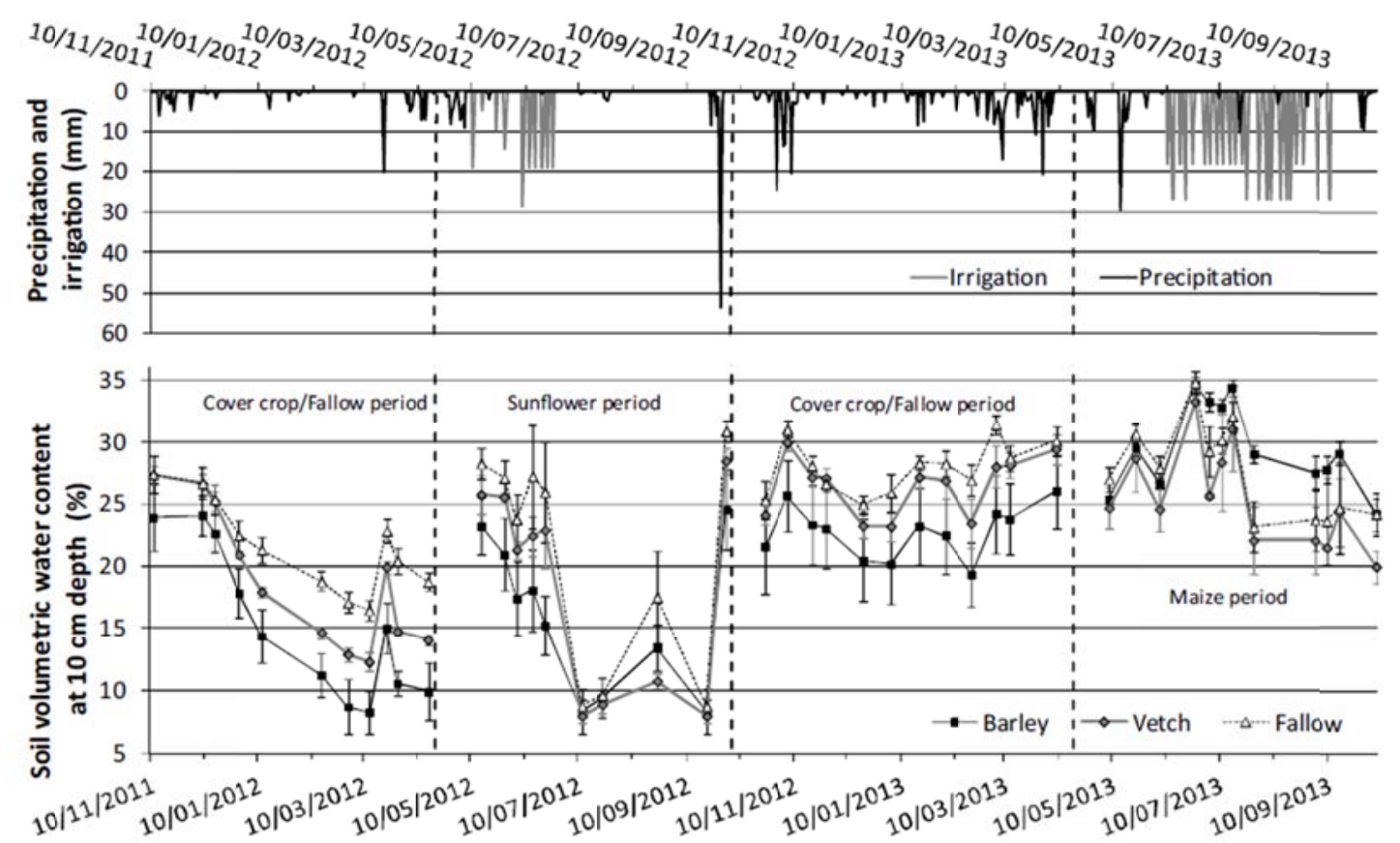

Fig. 1. Soil volumetric water content at $10 \mathrm{~cm}$ depth (mean \pm standard error) for the three treatments.

\subsection{Effect of soil cover}

In the sunflower season, no significant difference was observed among treatments in the root colonization percentage (Table 2). Nevertheless, the hyphae length and the number of AMF spores were significantly higher in the barley treatment than in the fallow and vetch treatments. Additionally, the EEGRSP content was higher in the barley treatment than in the fallow and vetch treatments. The highest $\beta$-glucosaminidase activity was observed in the barley, followed by the vetch and then the fallow treatment. The WSA was higher for the barley treatment than for the fallow, with the vetch in between. Compared with fallow, barley increased by $80 \%$ the values of hyphae length and $\beta$ glucosaminidase activity, while increments of $30 \%$ were found in the AMF spores, EE-GRSP and WSA. For most variables, vetch performance was more similar to fallow than to barley treatment. 
Table 2. Effect of the fallow, vetch and barley treatments on the variables directly related to arbuscular mycorrhizal fungi (AMF), the variables indirectly related to AMF (easily extractable glomalin-related soil protein, EE-GRSP, and $\beta$-glucosaminidase activity) and the percentage of water-stable aggregates (WSA) at 95 DAS sunflower in 2012 (mean \pm standard error).

\begin{tabular}{|c|c|c|c|}
\hline & Fallow & Vetch & Barley \\
\hline \multicolumn{4}{|l|}{ Variables directly related to $\mathrm{AMF}$} \\
\hline Root colonization $(\%)$ & $37.56 \pm 3.95 \mathrm{a}$ & $43.50 \pm 5.74 \mathrm{a}$ & $53.55 \pm 5.35 \mathrm{a}$ \\
\hline Hyphae length $\left(\mathrm{cmg}^{-1}\right)$ & $77.12 \pm 11.37 \mathrm{~b}$ & $82.36 \pm 9.47 \mathrm{~b}$ & $137.16 \pm 19.05 \mathrm{a}$ \\
\hline AMF spores (No. spores g ${ }^{-1}$ ) & $10.9 \pm 0.79 \mathrm{~b}$ & $11.0 \pm 1.11 \mathrm{~b}$ & $14.5 \pm 0.43 \mathrm{a}$ \\
\hline \multicolumn{4}{|l|}{ Variables indirectly related to AMF } \\
\hline EE-GRSP $\left(\mathrm{mgg}^{-1}\right)$ & $0.47 \pm 0.01 b$ & $0.49 \pm 0.041 \mathrm{~b}$ & $0.62 \pm 0.02 \mathrm{a}$ \\
\hline$\beta$ - Clucosaminidase activity ( $\mathrm{mg} \rho$-nitrophenol $\mathrm{kg}^{-1} \mathrm{~h}^{-1}$ ) & $13.61 \pm 1.24 \mathrm{C}$ & $18.07 \pm 0.6 \mathrm{~b}$ & $24.69 \pm 0.78 \mathrm{a}$ \\
\hline \multicolumn{4}{|l|}{ Soil structure stability } \\
\hline WSA (\%) & $40.10 \pm 2.01 \mathrm{~b}$ & $45.44 \pm 2.54 \mathrm{ab}$ & $51.02 \pm 1.50 \mathrm{a}$ \\
\hline
\end{tabular}

Means followed by different letters indicate significant differences among soil cover treatments according to Fisher's LSD at a 0.05 probability level.

In the maize season, on both dates, cover crop treatments had higher values of root colonization compared with the fallow treatment (Fig. 2). The root colonization increased with the time elapsed from sowing only for the vetch and fallow treatments. The results for the hyphae length and AMF spores were similar to the previous year with sunflower, with barley having higher values than the vetch and fallow treatments. The hyphae length increased with time for the three soil cover treatments. The AMF spores were only influenced by time in the barley treatment, decreasing at the second sampling date. The content of EE-GRSP at 54 DAS was higher for the barley treatment than for the vetch and fallow treatments. However, at 69 DAS, both barley and vetch had values that were significantly higher than the fallow treatment. The $\beta$-glucosaminidase activity in the barley and vetch treatments was higher than in the fallow at 54 DAS, but it was only higher in the barley at 69 DAS. The indirect variables were less affected by the sampling date. No significant differences were observed in EE-GRSP between the dates in each treatment, but differences between both $\mathrm{CC}$ and the fallow appeared on the second date. The $\beta$-glucosaminidase activity of the fallow treatment was the only indirect variable that increased at 69 DAS compared with the first date, suppressing the difference with the vetch but not with the barley treatment. The WSA showed significant differences among soil cover treatments at 54 DAS, with barley and vetch having the highest values. At 69 DAS, the trend remained but the differences were not significant at $p<0.05$. The WSA remained steady between dates as expected. The variables of hyphae length, number of spores and $\beta$-glucosaminidase activity were the most enhanced by CC in terms of percentage. Vetch matched barley only for root colonization and WSA, whereas for the remaining variables, vetch was more similar to fallow. 

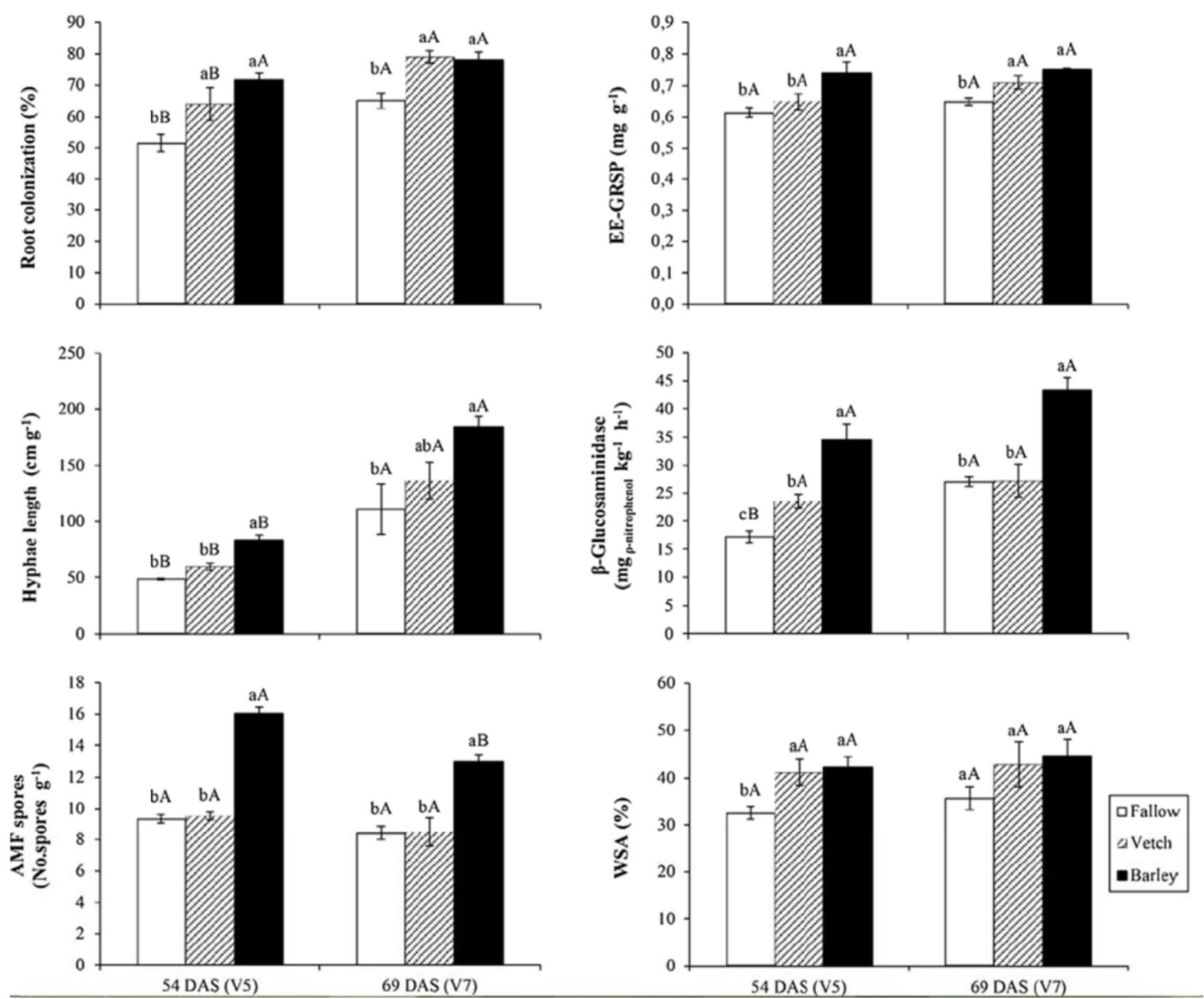

Fig. 2. Means of root colonization, hyphae length, AMF spores, easily extractable glomalinrelated soil protein (EE-GRSP), $\beta$-glucosaminidase activity and percentage of water-stable aggregates (WSA) at 54 and 69 DAS maize in 2013. Different lower case letters indicate significant differences among soil cover treatments according to Fisher's LSD at a 0.05 probability level. Different capital letters indicate significant differences between dates at a 0.05 probability level. The bars are the mean and the small bars are the standard error.

\subsection{Relationships between the fungal and soil variables}

Overall, this study showed positive relationships among the direct variables of AMF, the indirect variables and the WSA in both years of the experiment (Tables 3 and 4). In the sunflower season, root colonization was positively correlated with the hyphae length and was much weaker $(p<0.1)$ with the AMF spores (Table 3 ). In addition, the hyphae length and the AMF spores showed a weak $(p<0.1)$ but positive correlation. The EE-GRSP was positively correlated with AMF spores and showed the same tendency with the other two variables directly related to AMF. The $\beta$-glucosaminidase activity was also positively related to the hyphae length, AMF spores and EE-GRSP. The WSA was highly correlated with the hyphae length and $\beta$-glucosaminidase activity. 
Table 3. Correlation coefficients and significance levels among the direct variables (root colonization, hyphae length, AMF spores), the indirect variables (easily extractable glomalinrelated soil protein, EE-GRSP, and $\beta$-glucosaminidase activity) and the percentage of water stability aggregates (WSA) at 95 DAS sunflower in 2012.

\begin{tabular}{|c|c|c|c|c|c|}
\hline & Root colonization & Hyphae length & AMF spores & EE-GRSP & $\beta$-Glucosaminidase \\
\hline Hyphae length & $0.66^{\circ}$ & & & & \\
\hline AMF spores & $0.60^{*}$ & $0.60^{*}$ & & & \\
\hline EE-GRSP & $0.57^{*}$ & $0.55^{*}$ & $0.65^{\circ}$ & & \\
\hline$\beta$-Glucosaminidase & 0.44 & $0.71^{\circ}$ & $0.66^{\circ}$ & $0.73^{\circ}$ & \\
\hline WSA & 0.54 & $0.80^{* *}$ & 0.48 & 0.44 & $0.84^{* *}$ \\
\hline
\end{tabular}

$+,{ }^{*},{ }^{* *},{ }^{* * *}$, significant at $\mathrm{P}<0.1,0.05,0.01$ and 0.001 , respectively.

In the maize season, the correlations were similar to the previous year (Table 4). A relationship was observed between root colonization and the hyphae length. The content of EE-GRPS and the $\beta$-glucosaminidase activity were significantly related to each other and with all of the variables directly related to AMF, the root colonization, the hyphae length and the AMF spores. The WSA was correlated with the root colonization, EE-GRSP and $\beta$-glucosaminidase activity. It is noteworthy that the relationship with the hyphae length vanished. On both sampling dates in the sunflower and maize seasons, the linear correlation between the EE-GRSP and the root colonization became stronger ( $r$ $\left.=0.79^{* * *}\right)$ (Fig. 3).

Table 4. Correlation coefficients and significance levels among the direct variables (root colonization, hyphae length, AMF spores), the indirect variables (easily extractable glomalinrelated soil protein, EE-GRSP, and $\beta$-glucosaminidase activity) and the percentage of water stability aggregates (WSA) for the two sampling dates during maize cultivation in 2013.

\begin{tabular}{|c|c|c|c|c|c|}
\hline & Root colonization & Hyphae length & AMF spores & EE-GRSP & $\beta$-Glucosaminidase \\
\hline Hyphae length & $0.77 \cdots$ & & & & \\
\hline AMF spores & 0.27 & 0.19 & & & \\
\hline EE-GRSP & $0.56^{* *}$ & $0.57 *$ & $0.50^{\circ}$ & & \\
\hline B-Glucosaminidase & $0.68 \cdots$ & $0.74 \cdots$ & $0.56^{*}$ & $0.73 \cdots$ & \\
\hline WSA & $0.57 *$ & $0.38^{*}$ & 0.20 & $0.56^{* *}$ & $0.62 * *$ \\
\hline
\end{tabular}

$+,{ }^{*},{ }^{* *},{ }^{* * *}$, significant at $\mathrm{P}<0.1,0.05,0.01$ and 0.001 , respectively.

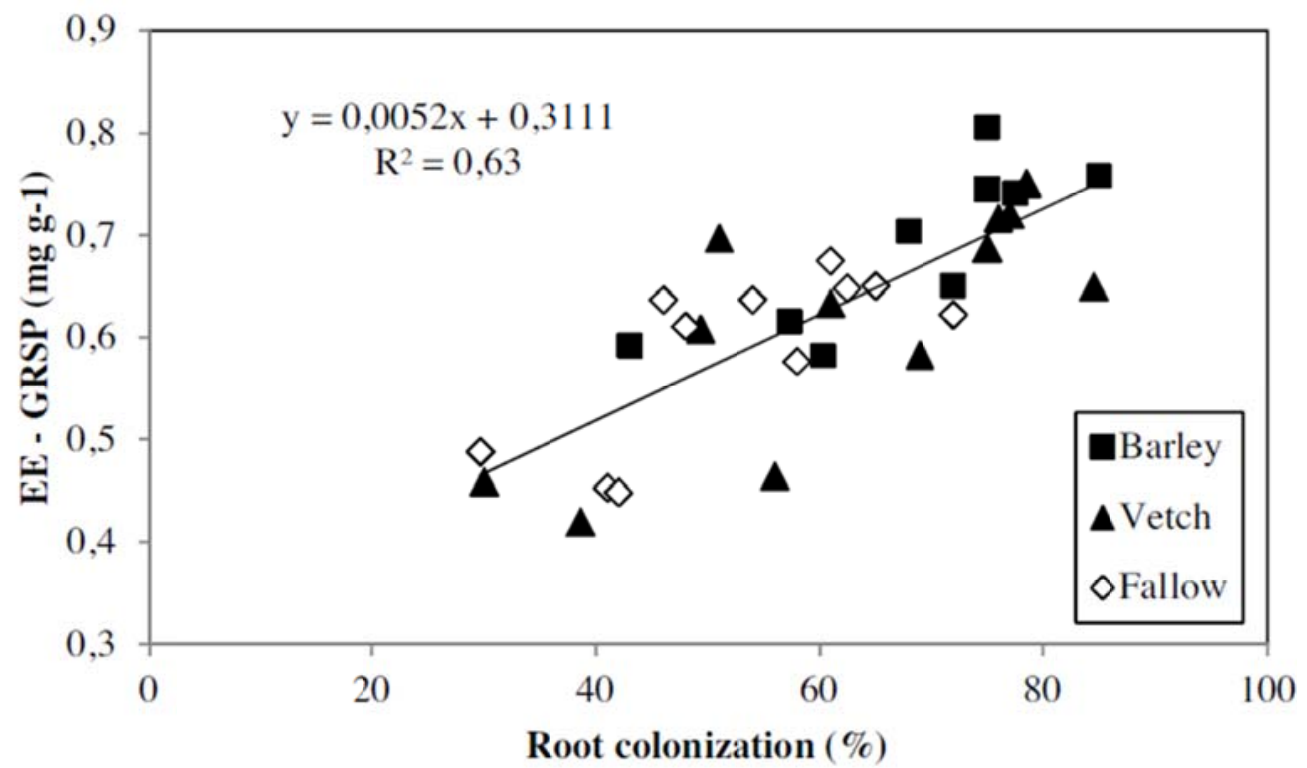

Fig. 3. Linear relationship between root colonization and easily extractable glomalin-related soil protein (EE-GRSP) for all dates in both years in the barley, vetch and fallow treatments. 


\section{Discussion}

In general, these results showed that replacing the winter fallow by a CC enhanced AMF in the subsequent main crop, either sunflower or maize. This result is consistent with other studies that highlighted the importance of the existence of a host for AMF during the intercrop period (Galvez et al., 1995; Kabir and Koide, 2002). The host plant supplies accommodations and carbohydrates for the formation, maintenance and function of mycorrhizal structures (Wright et al., 1998). Cover crops also modify some environmental conditions, such as soil water content at planting (Dabney et al., 2001), which is a major factor in the maintenance of AMF inoculum (Ruiz-Lozano and Azcon, 1996). In our study, the lowest soil water content associated with the barley treatment is in agreement with Gabriel et al. (2012), and it is related to a higher water consumption derived by the higher biomass of this CC (average 3.3 $\mathrm{Mg} / \mathrm{ha}$ from 7 campaigns) compared with vetch (average $1.9 \mathrm{Mg} / \mathrm{ha}$ from 7 campaigns) and fallow (no biomass). However, the lower water content in barley did not negatively affect mycorrhizal activity because in this cover we found the highest values of AMF parameters. The great root system from barley (Ramirez-Garcia et al., 2014), while offering a host for AMF, seems to compensate for the possible negative effect of the reduced water availability, even under the drier conditions of the 2011/12 season. Buyer et al. (2010) also found that the $\mathrm{CC}$ influence was more relevant than soil moisture or soil temperature in controlling AMF and other microbial biomass. Thus, in this study, the importance of $\mathrm{CC}$ as a host plant prevailed over the soil moisture reduction in the survival of the AMF inoculum. Therefore, the benefits of CC on AMF were maintained under the semiarid conditions of the Mediterranean climate.

The positive effects of $C C$ on direct AMF variables found in our study are in general agreement with other studies in the Mediterranean and other climatic areas. Most studies agreed that a variety of CC enhances root colonization in the subsequent maize crop (Boswell et al., 1998; Deguchi et al., 2007; Kabir and Koide, 2000, 2002; White and Weil, 2010), even under Mediterranean climate conditions (Njeru et al., 2014). Studies involving other main crops are scarce, but the effect of CC was similar, e.g., in leeks (Sorensen et al., 2005). In general, the percentages of increase relative to fallow in this study were moderate compared with other studies in which increments of 3-4-fold were found (Boswell et al., 1998; Kabir and Koide, 2002) or even 12-fold (Deguchi et al., 2007), probably because we found large values for root colonization even under fallow conditions. These large values may be related to the optimal temperature and soil moisture conditions from the beginning of maize growth. In the case of sunflower, the root colonization tended to be higher under CC but differences were not significant at $p<0.05$, probably because of the late sampling date (95 DAS) and the favorable environmental conditions. The high temperatures in summer and the irrigation system may have anticipated the 
equilibrium between $\mathrm{CC}$ and fallow conditions, erasing previous differences among treatments. In addition, as the sunflower continues to develop after sowing, the AMF and the remaining microbial community structure would have become more strongly influenced by the growing crop (Wortman et al., 2013). It would have been interesting to study different sampling dates during sunflower development, considering that the differences could appear in earlier stages.

In relation to the hyphae length, our results corroborated previous studies. The density of mycorrhizal hyphae under rye or oats cover treatments was twice that of fallow conditions (Kabir and Koide, 2002). In addition, Lehman et al. (2012) found that $\mathrm{CC}$ significantly increased the mycorrhizal inoculum potential measured using the most-probable-number, with forage oats being the most effective. The effect of CC on AMF spores has been less studied, and the results are not homogenous. We found that barley increased the number of spores by $42-72 \%$, but vetch was similar to fallow. This result differs from Galvez et al. (1995), who found that vetch had more spores number relative to fallow and from Boswell et al. (1998), who did not report differences between $\mathrm{CC}$ and fallow. The heterogeneity in the results may be due to the methodology. The process of spore count under a microscope may include nonviable spores, either because they are parasitized, old, broken or thick-walled (Walley and Germida,1995), which may give rise to an overcount. In addition there are AMF spores too small to be reliable extracted by wet sieving, so this method would generate a measurement error that should be taken into consideration. Furthermore, differences in spore number may be due to the variety in the sampling dates among studies, environmental conditions during the experiment or crop dependence on mycorrhizal which influence on the sporulation and spore germination (Declerck et al., 2001; Plenchette et al., 1983). Finally, we remark the different pattern for barley and vetch in both sunflower and maize crops in which the benefits to barley on AMF were larger compared to vetch. Higo et al. (2015) compared in a pot experiment the performance of four potential CCs (two legumes and two grasses) and found higher values of AMF colonization in the roots of barley compared with hairy vetch. They attributed these differences to host selectivity. The higher root colonization in barley during the $\mathrm{CC}$ season along with its greater root biomass may have enhanced propagule generation (Higo et al., 2013), favoring a greater infection in the subsequent crop.

Cover crops also enhanced the AMF indirect variables, in agreement with other studies. Wright and Anderson (2000) and Wright et al. (1999) in the USA, and Balota et al. (2014) in Brazil reported an increase in GRSP content associated with CC. In these studies, rotations with fallow or with CC were compared, and they observed that the GRSP content increased in the CC. The results obtained for $\beta$-glucosaminidase activity are in agreement with the studies of AcostaMartínez et al. (2011) and Ekenler and Tabatabai (2003) in the USA. They 
found that CC enhanced $\beta$-glucosaminidase activity and other enzymatic activities, which was attributed to increased biomass in the soil and/or the rhizosphere effect during winter. The order of barley $>$ vetch $>$ fallow for this enzyme activity in our study seems to follow the same order of the soil carbon content: barley $(1.5 \%) \geq$ vetch $(1.4 \%)>$ fallow $(1.2 \%)$ (data from October 2012 , not published). This result suggests a positive correlation between this enzymatic activity and the organic carbon content as previously reported by Ekenler and Tabatabai (2003).

We found contradictory results with regard to the influence of sampling date on the effect of CC. In the case of root colonization in maize, our results differ from other studies reporting that the differences between CC and fallow are found in the early sampling of the subsequent crop but tend to disappear with DAS (Deguchi et al., 2007; Sorensen et al., 2005; White and Weil, 2010). In contrast, this study showed significant differences (CC > fallow) until 69 DAS maize (V7) in both CC. These results agree with Kabir and Koide (2002), who found that the positive effect of CC on root colonization lasted until 68 DAS. Also in the case of the length of hyphae, the differences between barley and fallow remained significant until 69 DAS maize in contrast to the study of Kabir and Koide (2002), in which differences remained only until 27 DAS sweet corn. The AMF spore density is another parameter that has varied significantly between the two sampling dates for maize but only in the barley treatment. The decrease in the AMF spores may be due to spore germination enhanced by suitable moisture, temperature and $\mathrm{pH}$ conditions in the soil (Azcón-Aguilar and Barea, 1995). The different soils and environmental conditions among studies may generate these variations in results, in addition to the different covers or main crops used.

The relationship between the variables directly related to AMF and the GRSP content is a controversial topic. Most studies did not find correlations between AMF variables and glomalin (Lovelock et al., 2004; Lutgen et al., 2003; Rillig, 2004; Rillig et al., 2001a). In general, the lack of correlation is attributed to the different turnover between the AMF and the glomalin content. This was why we selected the glomalin fraction of more recent deposition in this study; i.e., the EE-GRSP. We found positive correlations between this glomalin fraction and the three AMF variables in maize and to a lesser extent in sunflower. Our results are in line with Bedini et al. (2013), who detected a strong correlation of GRSP with soil mycorrhizal inoculum potential determined in a bioassay, a moderate correlation with root colonization and no correlation with spore number. On the other hand, and in agreement with our results, a correlation between EE-GRSP and AMF spore density was found by Bedini et al. (2007) and Bai et al. (2009). The fact that spores constitute the most persistent component of fungal structures (Wright and Upadhyaya, 1998) and that the majority of glomalin is contained in hyphae and spores (Driver et al., 2005) 
could explain these positive correlations. According to our results, EE-GRSP could be considered as a biochemical indicator of AMF, with the advantage of being an easy, quick and inexpensive laboratory determination. In addition to EE-GRSP, $\beta$-glucosaminidase activity also showed positive correlations with the three studied AMF variables and with EE-GRSP in both sunflower and maize crops. This result is partially in line with the results obtained by Miller et al. (1998), Parham and Deng (2000) and Acosta- Martinez et al. (2004), who showed a relationship of $\beta$-glucosaminidase activity with soil fungal biomass. Our results suggest that this enzyme could be an easy fungi biomarker, but due to its weaker relationship with AMF, additional investigations are required to confirm that the $\beta$-glucosaminidase activity could be used as an AMF indicator.

In this study, we also included the WSA as a soil quality indicator. The replacement of fallow by $\mathrm{CC}$ has a positive effect on soil aggregation, as reported in several studies. For example, winter wheat and dandelion used as CC promoted WSA compared with fallow (Kabir and Koide, 2000). Villamil et al. (2006) also found the same effect with rye and vetch. In a semi-arid region in Spain, Muñoz et al. (2007) showed an increase in soil aggregate stability by using oats as a CC. In our study, barley and vetch increased WSA at 54 DAS maize; the differences disappeared at 69 DAS, although the trend remained. This lack of difference may be related to the higher soil moisture at sampling (Lammerding et al., 2011) due to irrigation. The enhancement of soil aggregation derived by $\mathrm{CC}$ introduction is normally attributed to the input of fresh plant residues in the soil, mainly particulate organic matter (Six et al., 2000), which is higher in vetch and barley. Soil aggregation is promoted by other biological factors, such as fungi and other soil microorganisms (Six et al., 2004). The fungal mycelium acts as a "sticky string bag" favoring the entangling and enmeshment of soil particles within the hyphae network to form macroaggregates (Miller and Jastrow, 2000). In addition, the glomalin produced by AMF seems to act as hydrophobic glue, improving water stability aggregation (Wright and Upadhyaya, 1998). In our case, the higher values of both extraradical mycelium and glomalin content under CC treatments may have contributed to improved soil aggregation. The positive correlations of WSA with the hyphae length in the case of sunflower $\left(r=0.80^{* *}\right)$ and with EE-GRSP $(r=$ $0.56^{* *}$ ) in maize seem to confirm that the replacement of fallow by CC enhances soil aggregate stability, therefore improving soil quality via AMF promotion.

\section{Conclusions}

The introduction of $\mathrm{CC}$ to replace the fallow periods enhanced AMF development in the subsequent sunflower and maize crops. It improved the variables directly related to AMF (mycorrhizal colonization, extra-radical 
mycelium and AMF spores) and some indirectly related variables (EE-GRSP and $\beta$-glucosaminidase activity), as well as the water-stable aggregates. Therefore, the benefits of CC on AMF were maintained under the semiarid conditions of the Mediterranean climate. In general, the use of barley as CC had a positive effect on all of the AMF variables compared to fallow, whereas the vetch treatment was intermediate. Thus, from the AMF promotion perspective, we recommend the use of a grass such as barley when replacing fallow by CC. Positive relationships were found between the variables directly related to AMF, EE-GRSP and $\beta$-glucosaminidase activity. These results suggest the possibility of using the determination of indirectly related variables, mainly the EE-GRSP, to rapidly, easily and economically estimate the AMF abundance. Further work is required to confirm this potential.

\section{Acknowledgments}

This work was supported by The Comisión Interministerial de Ciencia y Tecnología (project AGL2011-24732) and Comunidad de Madrid (project AGRISOST, S2013/AB1-2717). We would like to thank the staff from La Chimenea field station (Instituto Madrileño de Investigación y Desarrollo Rural, Agrario y Alimentario) and the research group of Mycorrhizas from the Department of Micro- biología del suelo y sistemas simbióticos in the Estación Experimental del Zaidín (Granada, Spain) for their helpful assistance.

\section{References}

Acosta-Martínez, V., Lascano, R., Calderón, F., Booker, J.D., Zobeck, T.M., Upchurch, D. R., 2011. Dryland cropping systems influence the microbial biomass and enzyme activities in a semiarid sandy soil. Biol. Fertil. Soils 47, 655-667.

Acosta-Martinez, V., Zobeck, T.M., Allen, V., 2004. Soil microbial, chemical and physical properties in continuous cotton and integrated crop-livestock systems. Soil Sci. Soc. Am. J. 68, 1875-1884.

Alguacil, M.M., Torrecillas, E., García-Orenes, F., Roldán, A., 2014. Changes in the composition and diversity of AMF communities mediated by management practices in a Mediterranean soil are related with increases in soil biological activity. Soil Biol. Biochem. 76, 34-44.

Allen, R.G., Pereira, L.S., Raes, D., Smith, M., 1998. Crop evapotranspirationguidelines for computing crop water requirements-FAO irrigation and drainage paper 56, 300. FAO, Rome D05109. 
Andersson, M., Kjøller, A., Struwe, S., 2004. Microbial enzyme activities in leaf litter, humus and mineral soil layers of European forests. Soil Biol. Biochem. 36, 1527- 1537.

Azcón-Aguilar, C., Barea, J.M., 1995. Saprophytic Growth of Arbuscular Mycorrhizal Fungi. Springer, pp. 391-407.

Azcón-Aguilar, C., Barea, J.M., 1997. Arbuscular mycorrhizas and biological control of soil-borne plant pathogens-an overview of the mechanisms involved. Mycorrhiza 6, 457-464.

Bai, C., He, X., Tang, H., Shan, B., Zhao, L., 2009. Spatial distribution of arbuscular mycorrhizal fungi, glomalin and soil enzymes under the canopy of Astragalus adsurgens Pall. in the Mu Us sandland, China. Soil Biol. Biochem. 41, 941-947.

Balota, E.L., Machineski, O., Honda, C., Yada, I.F.U., Barbosa, G., Nakatani, A.S., Coyne, M.S., 2014. Response of arbuscular mycorrhizal fungi in different soil tillage systems to long-term swine slurry application. Land Degrad. Dev..

Barea, J.M., Palenzuela, J., Cornejo, P., Sánchez-Castro, I., NavarroFernández, C., Lopéz-García, A., Estrada, B., Azcón, R., Ferrol, N., AzcónAguilar, C., 2011. Ecological and functional roles of mycorrhizas in semi-arid ecosystems of Southeast Spain. J. Arid Environ. 75, 1292-1301.

Bedini, S., Avio, L., Argese, E., Giovannetti, M., 2007. Effects of long-term land use on arbuscular mycorrhizal fungi and glomalin-related soil protein. Agric. Ecosyst. Environ. 120, 463-466.

Bedini, S., Avio, L., Sbrana, C., Turrini, A., Migliorini, P., Vazzana, C., Giovannetti, M., 2013. Mycorrhizal activity and diversity in a long-term organic Mediterranean agroecosystem. Biol. Fertil. Soils 49, 781-790.

Boswell, E.P., Koide, R.T., Shumway, D.L., Addy, H.D., 1998. Winter wheat cover cropping, VA mycorrhizal fungi and maize growth and yield. Agric. Ecosyst. Environ. 67, 55-65.

Bowman, G., Shirley, C., 2000. Benefits of cover crops. In: Clark, A. (Ed.), Managing Cover Crops Profitably. Sustainable Agriculture Network, Beltsville (USA), pp. 9- 11.

Bronick, C.J., Lal, R., 2005. Soil structure and management: a review. Geoderma 124, 3-22. Buyer, J.S., Teasdale, J.R., Roberts, D.P., Zasada, I.A., Maul, J.E., 2010. Factors affecting soil microbial community structure in tomato cropping systems. Soil Biol. Biochem. 42, 831-841.

Dabney, S.M., Delgado, J.A., Reeves, D.W., 2001. Using winter cover crops to improve soil and water quality. Commun. Soil Sci. Plant Anal. 32, 1221-1250. 
Declerck, S., D'or, D., Cranenbrouck, S., Boulengé, L.E., 2001. Modelling the sporulation dynamics of arbuscular mycorrhizal fungi in monoxenic culture. Mycorrhiza 11, 225-230.

Deguchi, S., Shimazaki, Y., Uozumi, S., Tawaraya, K., Kawamoto, H., Tanaka, O., 2007. White clover living mulch increases the yield of silage corn via arbuscular mycorrhizal fungus colonization. Plant Soil 291, 291-299.

Driver, J.D., Holben, W.E., Rillig, M.C., 2005. Characterization of glomalin as a hyphal wall component of arbuscular mycorrhizal fungi. Soil Biol. Biochem. 37, 101- 106.

Ekenler, M., Tabatabai, M.A., 2003. Tillage and residue management effects on $\beta$-glucosaminidase activity in soils. Soil Biol. Biochem. 35, 871-874.

Gabriel, J.L., Quemada, M., 2011. Replacing bare fallow with cover crops in a maize cropping system: yield, $\mathrm{N}$ uptake and fertiliser fate. Eur. J. Agron. 34, 133-143.

Gabriel, J.L., Lizaso, J.I., Quemada, M., 2010. Laboratory versus field calibration of capacitance probes. Soil Sci. Soc. Am. J. 74, 593-601.

Gabriel, J.L., Muñoz-Carpena, R., Quemada, M., 2012. The role of cover crops in irrigated systems: water balance, nitrate leaching and soil mineral nitrogen accumulation. Agric. Ecosyst. Environ. 155, 50-61.

Gabriel, J.L., Garrido, A., Quemada, M., 2013. Cover crops effect on farm benefits and nitrate leaching: linking economic and environmental analysis. Agric. Syst. 121, 23-32.

Galvez, L., Douds, D.D., Wagoner, P., Longnecker, L.R., Drinkwater, L.E., Janke, R.R., 1995. An overwintering cover crop increases inoculum of VAM fungi in agricultural soil. Am. J. Altern. Agric. 10, 152-156.

Gavito, M.E., Miller, M.H., 1998. Changes in mycorrhiza development in maize induced by crop management practices. Plant Soil 198, 185-192.

Geisseler, D., Horwath, W.R., 2009. Relationship between carbon and nitrogen availability and extracellular enzyme activities in soil. Pedobiologia 53, 87-98.

Giovannetti, M., Mosse, B., 1980. An evaluation of techniques for measuring vesicular arbuscular mycorrhizal infection in roots. New Phytol. 84, 489-500.

Higo, M., Isobe, K., Yamaguchi, M., Drijber, R.A., Jeske, E.S., Ishii, R., 2013. Diversity and vertical distribution of indigenous arbuscular mycorrhizal fungi under two soybean rotational systems. Biol. Fertil. Soils 49, 1085-1096.

Higo, M., Isobe, K., Drijber, R.A., Kondo, T., Yamaguchi, M., Takeyama, S., Suzuki, Y., Niijima, D., Matsuda, Y., Ishii, R., 2014. Impact of a 5-year winter 
cover crop rotational system on the molecular diversity of arbuscular mycorrhizal fungi colonizing roots of subsequent soybean. Biol. Fert. Soils 50, 913-926.

Higo, M., Isobe, K., Matsuda, Y., Ichida, M., Torigoe, Y., 2015. Influence of sowing season and host crop identity on the community structure of arbuscular mycorrhizal fungi colonizing roots of two different gramineous and leguminous crop species. Adv. Microbiol. 5, 107.

Jakobsen, I., Abbott, L.K., Robson, A.D.,1992. External hyphae of vesiculararbuscular mycorrhizal fungi associated with Trifolium subterraneum L. New Phytol. 120, 371-380.

Jeffries, P., Gianinazzi, S., Perotto, S., Turnau, K., Barea, J.-M., 2003. The contribution of arbuscular mycorrhizal fungi in sustainable maintenance of plant health and soil fertility. Biol. Fertil. Soils 37, 1-16.

Kabir, Z., Koide, R.T., 2000. The effect of dandelion or a cover crop on mycorrhiza inoculum potential, soil aggregation and yield of maize. Agric. Ecosyst. Environ. 78, 167-174.

Kabir, Z., Koide, R.T., 2002. Effect of autumn and winter mycorrhizal cover crops on soil properties, nutrient uptake and yield of sweet corn in Pennsylvania, USA. Plant Soil 238, 205-215.

Kabir, Z., O'halloran, I.P., Fyles, J.W., Hamel, C., 1997. Seasonal changes of arbuscular mycorrhizal fungi as affected by tillage practices and fertilization: hyphal density and mycorrhizal root colonization. Plant Soil 192, 285-293.

Kemper, W.D., Rosenau, R.C., 1986. Aggregate stability and size distribution. In: Klute, A. (Ed.), Methods of Soil Analysis. Part 1. Agron. Monog., 9. ASA, Madison, WI, pp. 425-442.

Kuo, S., Sainju, U.M., Jellum, E.J., 1997. Winter cover crop effects on soil organic carbon and carbohydrate in soil. Soil Sci. Soc. Am. J. 61, 145-152.

Lammerding, D.M., Hontoria, C., Tenorio, J.L., Walter, I., 2011. Mediterranean dryland farming: effect of tillage practices on selected soil properties. Agron. J. 103, 382-389.

Lehman, R.M., Taheri, W.I., Osborne, S.L., Buyer, J.S., Douds Jr., D.D., 2012. Fall cover cropping can increase arbuscular mycorrhizae in soils supporting intensive agricultural production. Appl. Soil Ecol. 61, 300-304.

Lekberg, Y., Koide, R.T., 2005. Arbuscular mycorrhizal fungi, rhizobia, available soil $P$ and nodulation of groundnut (Arachis hypogaea) in Zimbabwe. Agric. Ecosyst. Environ. 110, 143-148. 
Lovelock, C.E., Wright, S.F., Nichols, K.A., 2004. Using glomalin as an indicator for arbuscular mycorrhizal hyphal growth: an example from a tropical rain forest soil. Soil Biol. Biochem. 36, 1009-1012.

Lutgen, E.R., Muir-Clairmont, D., Graham, J., Rillig, M.C., 2003. Seasonality of arbuscular mycorrhizal hyphae and glomalin in a western Montana grassland. Plant Soil 257, 71-83.

Miller, R.M., Jastrow, J.D., 2000. Mycorrhizal Fungi Influence Soil Structure. Springer, pp. 3-18.

Miller, M., Palojarvi, A., Rangger, A., Reeslev, M., Kjoller, A., 1998. The use of fluorogenic substrates to measure fungal presence and activity in soil. Appl. Environ. Microbiol. 64, 613-617.

Morton, J.B., Redecker, D., 2001. Two new families of Glomales, Archaeosporaceae and Paraglomaceae, with two new genera Archaeospora and Paraglomus, based on concordant molecular and morphological characters. Mycologia 181-195.

Muñoz, A., López-Piñeiro, A., Ramírez, M., 2007. Soil quality attributes of conservation management regimes in a semi-arid region of south western Spain. Soil Tillage Res. 95, 255-265.

Njeru, E.M., Avio, L., Sbrana, C., Turrini, A., Bocci, G., Bàrberi, P., Giovannetti, M., 2014. First evidence for a major cover crop effect on arbuscular mycorrhizal fungi and organic maize growth. Agron. Sustain. Dev. 34, 841-848.

Ortiz, N., Armada, E., Duque, E., Roldán, A., Azcón, R., 2015. Contribution of arbuscular mycorrhizal fungi and/or bacteria to enhancing plant drought tolerance under natural soil conditions: effectiveness of autochthonous or allochthonous strains. J. Plant Physiol. 174, 87-96.

Paltineanu, I.C., Starr, J.L., 1997. Real-time soil water dynamics using multisensor capacitance probes: laboratory calibration. Soil Sci. Soc. Am. J. 61, 1576-1585.

Papadakis, J., 1966. Climates of the World and Their Agricultural Potencialities. DAPCP, Rome, Italy.

Parham, J.A., Deng, S.P., 2000. Detection, quantification and characterization of $\beta$-glucosaminidase activity in soil. Soil Biol. Biochem. 32, 1183-1190.

Peng, S., Guo, T., Liu, G., 2013. The effects of arbuscular mycorrhizal hyphal networks on soil aggregations of purple soil in southwest China. Soil Biol. Biochem. 57, 411-417. 
Phillips, J.M., Hayman, D.S., 1970. Improved procedures for clearing roots and staining parasitic and vesicular-arbuscular mycorrhizal fungi for rapid assessment of infection. Tran. Br. Mycol. Soc. 55 (158-IN118).

Plenchette, C., Fortin, J., Furlan, V., 1983. Growth responses of several plant species to mycorrhizae in a soil of moderate P-fertility. Plant Soil 70, 199-209.

Ramirez-Garcia, J., Martens, H.J., Quemada, M., Thorup-Kristensen, K., 2014. Intercropping effect on root growth and nitrogen uptake at different nitrogen levels. J. Plant Ecol. rtu024.

Reeslev, M., Miller, M., Nielsen, K.F., 2003. Quantifying mold biomass on gypsum board: comparison of ergosterol and beta-N-acetylhexosaminidase as mold biomass parameters. Appl. Environ. Microbiol. 69, 3996-3998.

Rillig, M.C., Mummey, D.L., 2006. Mycorrhizas and soil structure. New Phytol. 171, 41-53.

Rillig, M.C., Wright, S.F., Kimball, B.A., Pinter, P.J., Wall, G.W., Ottman, M.J., Leavitt, S. W., 2001a. Elevated carbon dioxide and irrigation effects on water stable aggregates in a Sorghum field: a possible role for arbuscular mycorrhizal fungi. Global Change Biol. 7, 333-337.

Rillig, M.C., Wright, S.F., Nichols, K.A., Schmidt, W.F., Torn, M.S., 2001b. Large contribution of arbuscular mycorrhizal fungi to soil carbon pools in tropical forest soils. Plant Soil 233, 167-177.

Rillig, M.C., 2004. Arbuscular mycorrhizae, glomalin, and soil aggregation. Can. J. Soil Sci. 84, 355-363.

Ritchie, S.W., Hanway, J.J., Benson, G.O., 1992. How a corn plant develops. Special Report Nro. 48. lowa State University of Science and Technology, Ames, lowa, pp. 21.

Ruiz-Lozano, J.M., Azcon, R., 1996. Viability and infectivity of mycorrhizal spores after long term storage in soils with different water potentials. Appl. Soil Ecol. 3, 183-186.

Sieverding, E., 1991. Vesicular-Arbuscular Mycorrhiza Managament in Tropical Agrosystems. GTZ, Eschborn, Germany pp. 371.

Six, J., Elliott, E.T., Paustian, K., 2000. Soil macroaggregate turnover and microaggregate formation: a mechanism for $\mathrm{C}$ sequestration under no-tillage agriculture. Soil Biol. Biochem. 32, 2099-2103.

Six, J., Bossuyt, H., Degryze, S., Denef, K., 2004. A history of research on the link between (micro) aggregates, soil biota, and soil organic matter dynamics. Soil Tillage Res. 79, 7-31. 
Sorensen, J.N., Larsen, J., Jakobsen, I., 2005. Mycorrhiza formation and nutrient concentration in leeks (Allium porrum) in relation to previous crop and cover crop management on high P soils. Plant Soil 273, 101-114.

Staff, S.S., 2003. Keys to Soil Taxonomy, 9th edition Natural Resources Conservation Service, USDA, Washington.

Steinberg, P.D., Rillig, M.C., 2003. Differential decomposition of arbuscular mycorrhizal fungal hyphae and glomalin. Soil Biol. Biochem. 35, 191-194.

Tennant, D., 1975. A test of a modified line intersect method of estimating root length. J. Ecol. 995-1001.

Van Der Heijden, M.G., Streitwolf-Engel, R., Riedl, R., Siegrist, S., Neudecker, A., Ineichen, K., Boller, T., Wiemken, A., Sanders, I.R., 2006. The mycorrhizal contribution to plant productivity, plant nutrition and soil structure in experimental grassland. New Phytol. 172, 739-752.

Villamil, M.B., Bollero, G.A., Darmody, R.G., Simmons, F.W., Bullock, D.G., 2006. No-till corn/soybean systems including winter cover crops. Soil Sci. Soc. Am. J. 70, 1936-1944.

Walley, F.L., Germida, J.J., 1995. Estimating the viability of vesicular-arbuscular mycorrhizae fungal spores using tetrazolium salts as vital stains. Mycologia 273-279.

White, C.M., Weil, R.R., 2010. Forage radish and cereal rye cover crop effects on mycorrhizal fungus colonization of maize roots. Plant Soil 328, 507-521.

Wortman, S.E., Francis, C.A., Bernards, M.A., Blankenship, E.E., Lindquist, J.L., 2013. Mechanical termination of diverse cover crop mixtures for improved weed suppression in organic cropping systems. Weed Sci. 61, 162-170.

Wright, S.F., Anderson, R.L., 2000. Aggregate stability and glomalin in alternative crop rotations for the central Great Plains. Biol. Fertil. Soils 31, 249253.

Wright, S.F., Upadhyaya, A., 1998. A survey of soils for aggregate stability and glomalin, a glycoprotein produced by hyphae of arbuscular mycorrhizal fungi. Plant Soil 198, 97-107.

Wright, S.F., Upadhyaya, A., 1999. Quantification of arbuscular mycorrhizal fungi activity by the glomalin concentration on hyphal traps. Mycorrhiza 8, 283285.

Wright, D.P., Read, D.J., Scholes, J.D., 1998. Mycorrhizal sink strength influences whole plant carbon balance of Trifolium repens L. Plant. Cell Environ.t 21, 881- 891. 
Wright, S.F., Starr, J.L., Paltineanu, I.C., 1999. Changes in aggregate stability and concentration of glomalin during tillage management transition. Soil Sci. Soc. Am. J. 63, 1825-1829. 